\title{
LOADING, UNLOADING AND RELOADING ON SQUARE FOOTING WITH GEOGRID AS A REINFORCEMENT
}

\author{
Shweta N Vantamuri ${ }^{1}$, P.G.Rakaraddi ${ }^{2}$ \\ ${ }^{\text {I}}$ Post graduate student, Geotechnical engineering, Department of civil engineering, Basaveshwar engineering college, \\ Bagalkot, Karnataka, India \\ ${ }^{2}$ Professor, Department of civil engineering, Basaveshwar engineering college, Bagalkot, Karnataka, India
}

\begin{abstract}
Superstructure transmits its loads to the foundation, and then to ground. Loading, unloading and reloading is happens in petroleum tanks and ship repair tracks. This paper presents laboratory tests were carried out on square footing having dimensions of $0.1 \times 0.1 \mathrm{~m}$ for different densities of $16.10 \mathrm{kN} / \mathrm{m}^{3}, 16.89 \mathrm{kN} / \mathrm{m}^{3}, 17.29 \mathrm{kN} / \mathrm{m}^{3}$.Coated yarn geogrid is used as reinforcing material. In the present. Paper investigations were carried on by varying number of reinforcement layers such as $N=$ 0,1 2, 3.Drawn conclusion is as density of foundation bed increases, settlement of the footing decreases and as number of layers of reinforcement increases, settlement of the footing reduces.
\end{abstract}

Keywords: Geogrid, square footing, LVDT, loading, unloading, reloading

\section{INTRODUCTION}

Foundation is lowest part of structure. A properly designed foundation transfers load throughout the soil without overstressing of soil. Overstressing of soil result in excessive settlement or shear failure of soil. In the present study investigations were carried out on the loading, unloading and reloading on square footing with geogrid as a reinforcement material. Varied parameter is number of reinforcement layer $(\mathrm{N}=0,1,2,3$.)

\section{EXPERIMENTAL STUDY}

\subsection{Test Equipment}

The tests were performed in a tank with length, breadth, and width of $60 \mathrm{~cm}$. Sides of the box is stiffened with the help of battens. The test tank is filled by raining technique as shown in the figure.1.

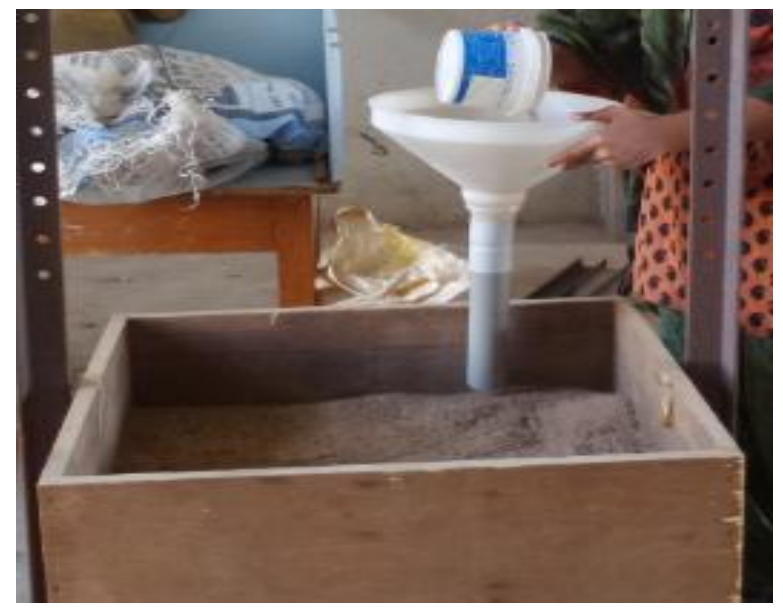

Fig 1: Sand pouring technique
Sand is poured from the funnel by maintaining required distance of free fall to achieve required density. Experimental setup is shown in fig 2.

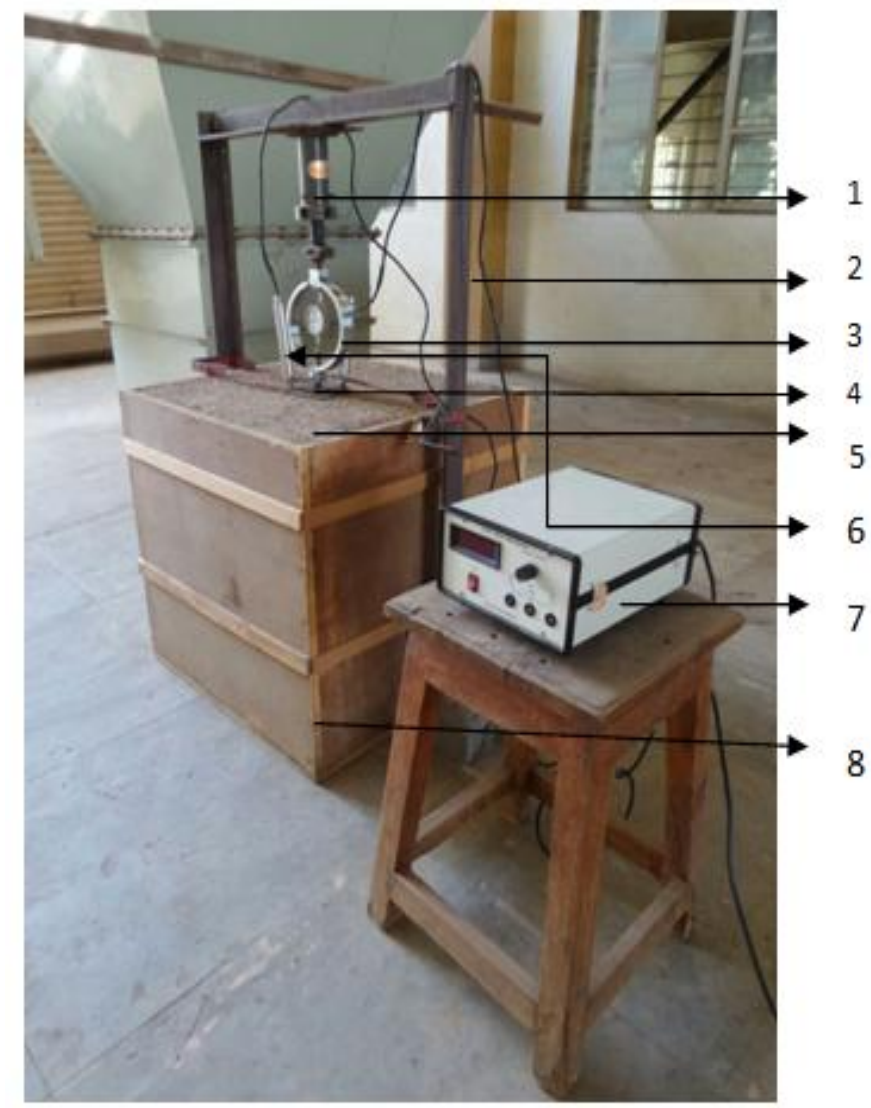

Fig 2: Experimental setup in laboratory 1)Screw jack, 2) Loading frame 3)Proving ring 4)Model footing 5)Sand 6)LVDT 7) LVDT display unit 8) Test tank 
Load is transferred via metallic ball to model footing to sand beneath it. LVDT (linear varying displacement transducer) is used to measure settlement of the footing. Coated yarn geogrid is used as reinforcing material.

\subsection{Soil}

Locally available Malaprabha river sand was used for present study. Properties of sand are given in table 1 .

Table 1: Properties of sand

\begin{tabular}{|c|c|c|}
\hline Sl. No. & Parameters & Results \\
\hline \multirow[t]{2}{*}{1} & Sieve analysis & \\
\hline & $\begin{array}{l}\text { Effective Size, } D_{10}(\mathrm{~mm}) \\
\mathrm{D}_{30}(\mathrm{~mm}) \\
\mathrm{D}_{60}(\mathrm{~mm}) \\
\text { Uniformity } \\
\left(\mathrm{C}_{\mathrm{u}}\right) \\
\text { Coefficient of coefficient } \\
\left(\mathrm{C}_{\mathrm{c}}\right)\end{array}$ & $\begin{array}{l}0.40 \\
0.50 \\
1.10 \\
2.75 \\
\\
0.56\end{array}$ \\
\hline 2 & Specific Gravity (G) & 2.51 \\
\hline 3 & $\begin{array}{l}\text { Maximum Dry unit weight } \\
\gamma\left(\mathrm{kN} / \mathrm{m}^{3}\right)\end{array}$ & 17.29 \\
\hline 4 & $\begin{array}{l}\text { Minimum dry unit weight } \\
\gamma\left(\mathrm{kN} / \mathrm{m}^{3}\right)\end{array}$ & 16.10 \\
\hline 5 & $\begin{array}{l}\text { Angle of internal friction } \\
(\varphi) \text { for density } \\
\text { Maximum dry unit weight } \\
-17.29 \mathrm{kN} / \mathrm{m}^{3} \\
\text { Minimum dry unit weight } \\
-16.10 \mathrm{kN} / \mathrm{m}^{3}\end{array}$ & $\begin{array}{l}38 \\
32\end{array}$ \\
\hline
\end{tabular}

From these results, Soil classified as poorly graded sand.

\subsection{Placing Of Geogrid}

First the test is done without reinforcement and for the test with reinforcement, the geogrid layer is placed at a depth of .33B [10] from the base of footing. Fig 3 shows the placing of geogrid. Since in this test, width of square footing is $0.1 \mathrm{~m}$, the depth of first layer for layer 1 is taken as $3.3 \mathrm{~cm}$ from base of the footing and width of reinforcement is $60 \mathrm{~cm}$ For $2^{\text {nd }}$ layer, first layer is at $3.3 \mathrm{~cm}$ and next is at $8.2 \mathrm{~cm}$ from the first layer and for $3^{\text {rd }}$ layer first layer is at $3.3 \mathrm{~cm}$, second and third layers at $5.5 \mathrm{~cm}$ from first layer and second layer.

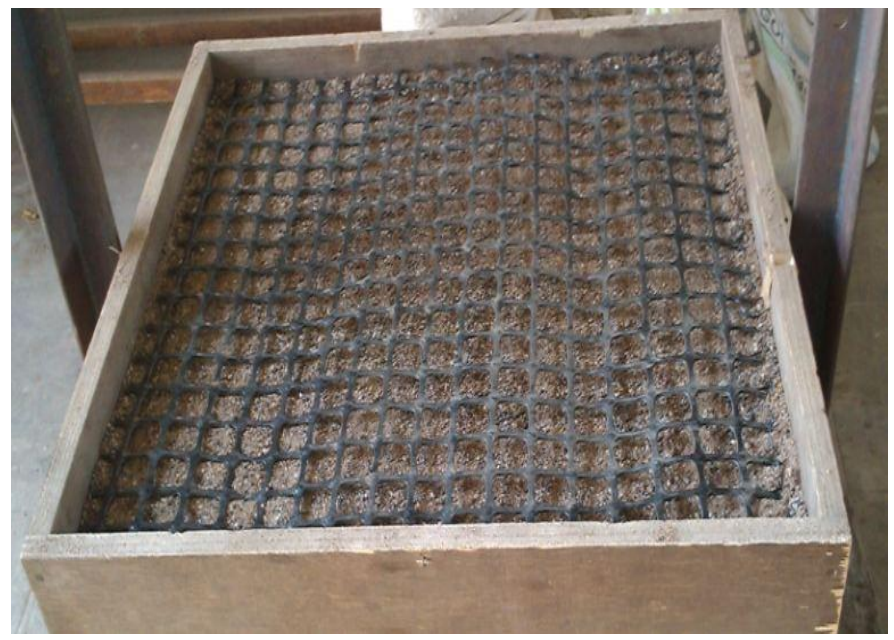

Fig 3 Placing of geogrid at $3.3 \mathrm{~cm}$ from the base of the footing

\section{RESULTS AND DISCUSSIONS}

From the obtained results from laboratory tests following curves are plotted.

\subsection{Pressure Settlement Curves}

These curves are plotted for $\mathrm{N}=0,1,2,3$, for different densities.

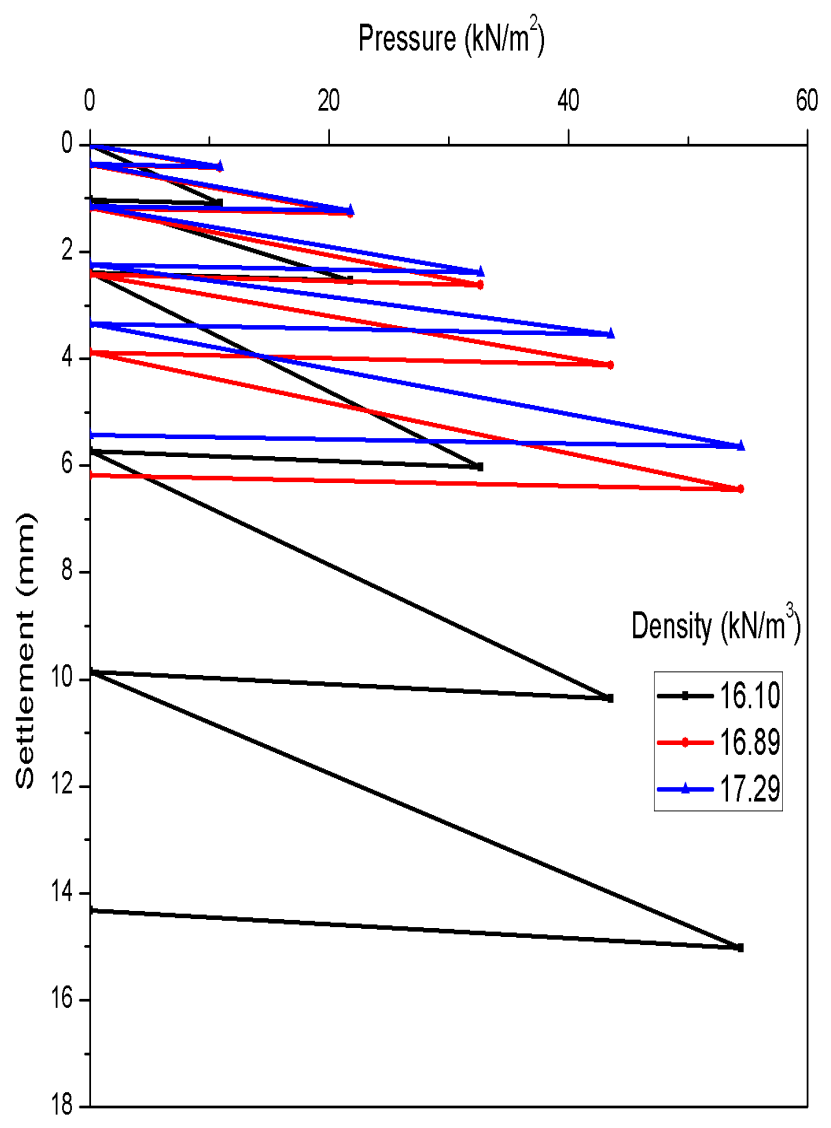

Fig 4: Pressure settlement curves for $\mathrm{N}=0$ with different densities for square footing 


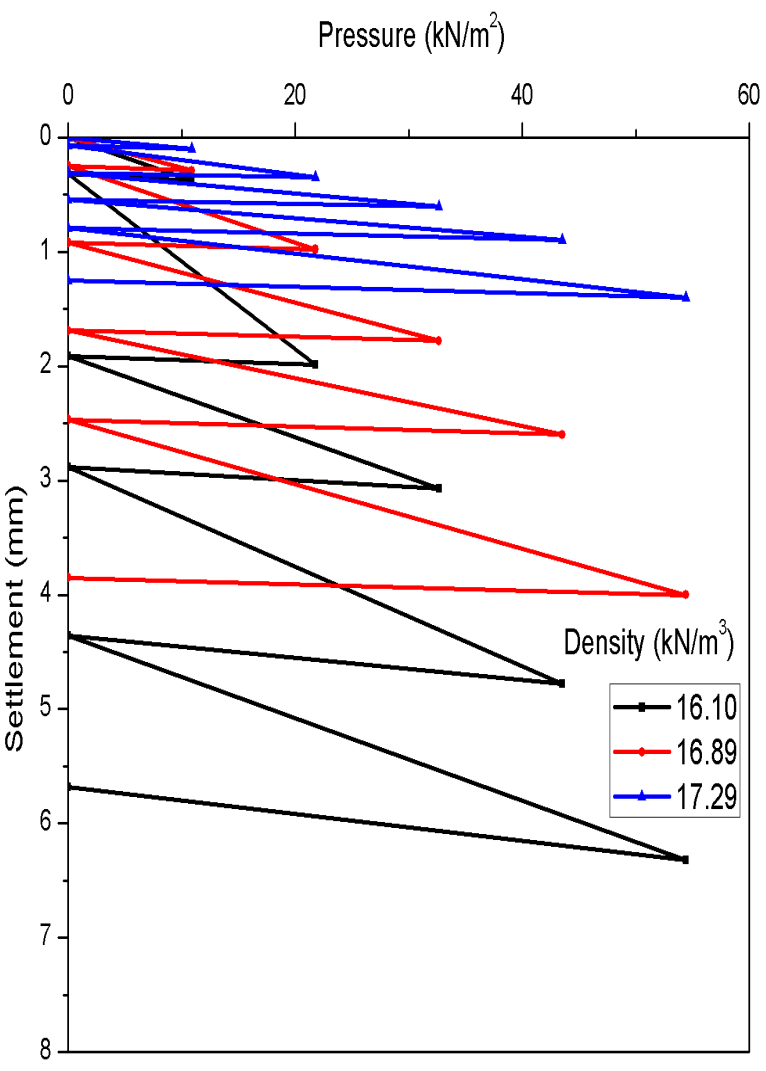

Fig 5: Pressure settlement curves for $\mathrm{N}=1$ with different densities for square footing

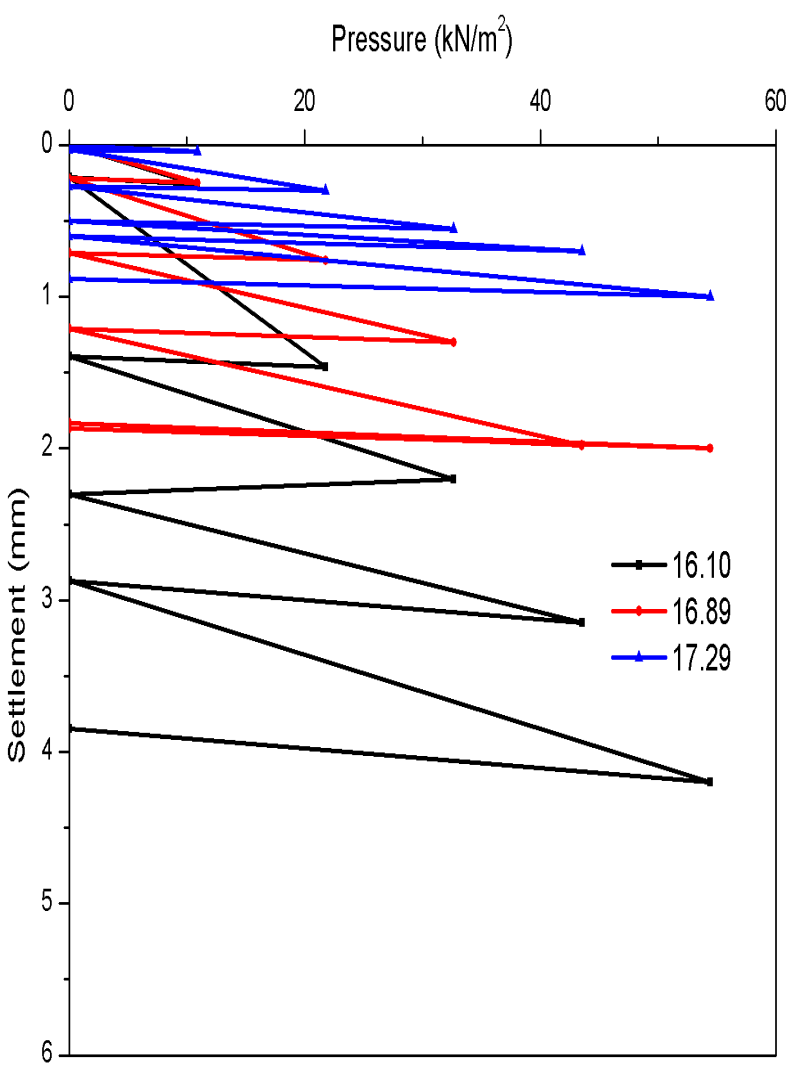

Fig 6: Pressure settlement curves for $\mathrm{N}=2$ with different densities for square footing

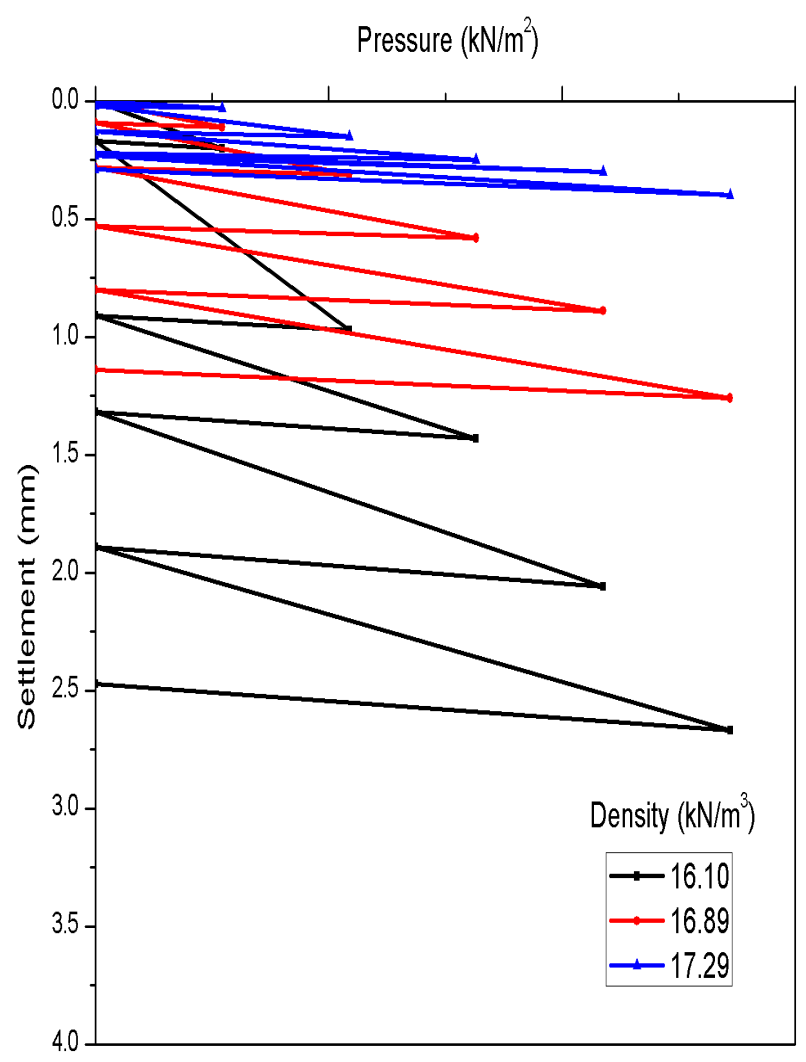

Fig 7: Pressure settlement curves for $\mathrm{N}=3$ with different densities for square footing

\section{CONCLUSION}

From the above graphs it can be concluded that, with use of geogrid settlement of the footing can be reduced. As number of layers increases, Settlement of the footing decreases and as the density of foundation bed increases, it leads to decrease in settlement.

\section{REFERENCES}

[1] A.K. Verma, A.R. Santha Kumar And T.V. Appa Rao, "Geogrid reinforced Sub Grades Under Simulated Earthquake Loading”, Proc. Of Ind. Geot. Conf., Baroda, 2000, Pp.281-282.

[2] M. R. Samal, "The Dynamic Behaviour Of Fibre Reinforced Sand", International Journal Of Advanced Technology In Civil Engineering, V01. 5, No.5, 2005, Pp.443-458.

[3] S.N. Moghaddas, S.E. Zarei And Y. Soltanpour, "Cyclic Loading On Foundation To Evaluate The Coefficient Of Elastic Uniform Compression Of Sand",Geotextiles And Geomembranes, Vol. 26, No. 8, 2006, Pp. 145-163.

[4] S.N. Moghaddas Tafreshi , S.E. Zarei And Y. Soltanpour "Cyclic Loading On Foundation To Evaluate The Coefficient Of Elastic Uniform Compression Of Sand", The $14^{\text {th }}$ World Conference On Earthquake Engineering October 12-17, 2008, Beijing, China 
[5] Vinod P, Ajitha Bhaskar And Sreehari, "Behaviour Of Cyclic Square Model Footing On Loose Sand Reinforced With Braided Coir Rope", Geotextiles And Geomembranes, Vol. 27, No. 5, 2009, Pp. 464474.

[6] N. Hataf, A.H. Boushehrian And A. Ghahramani, "Experimental And Numerical Behaviour Of Shallow Foundations On Sand Reinforced With Geogrid And Grid Anchor Under Cyclic Loading”, Transaction A: Civil Engineering Vol. 17, No. 1, 2008, Pp. 1-10.

[7] Mostafa El Sawwaf And Ashraf Kamal Nazir "Behavior Of Repeatedly Loaded Rectangular Footings Resting On Reinforced Sand", Alexandria Engineering Journal 2010,Pp. 349-356.

[8] S. N. Moghaddas Tafreshi, Gh. Tavakoli Mehrjardi, M. Ahmad " Experimental And Numerical Investigation On Circular Footing Subjected To Incremental Cyclic Loads" International Journal Of Civil Engineering, Vol. 9, No. 4, December 2011

[9] H.N Ramesh, Dr.L.Manjesh, Vijaya Kumar.H.A."Effect Of Static And Cyclic Loading On Behavior Of Fiber Reinforced Sand" Iosr Journal Of Engineering (I Vol. 3, Issue 9 (September. 2013), Pp 56-63

[10] Basavraj Hotti, P.G. Rakaraddi, Sudhrani Kodde, "Behavior Of Square Footing Resting On Rreinforced Sand Subjected To Incremental Loading And Unloading " International Journal Of Research In Engineering And Technology, Volume: 03 Special Issue: 06 , May-2014.

[11] U.B.Choubey, Dipesh Goswami, Ankur Karma “ Experimental study of various shaped isolated footings under monotonic and incremental cyclic loading on sandy soil".

[12] Indian Standard -IS :2720 (Part 3) "Methods of tests for soils, determination of specific gravity, fine ,medium and coarse grained soils", New Delhi, India.

[13] Indian Standard - IS: 2720 (Part 4) - 1985, "Method of test for soils, grain size analysis-mechanical method", New Delhi, India.

[14] Indian Standard - IS: 2720 (Part 13) - 1986, "Method of test for soils, direct shear test", New Delhi, India. 